\title{
THE EFFECTIVENESS OF KNOW-WANT- LEARNED (KWL) STRATEGY IN IMPROVING READING COMPREHENSION OF THE EIGHT GRADE STUDENTS OF SMP NEGERI 14 PALU
}

\author{
Moh Syafi'i \\ Nurdin Nurdin \\ Fitriningsih \\ English Tadris Department, Teacher Training And Tarbiyah Faculty \\ State Institute of Islamic Studies \\ Email: muhsyafii279@gmail.com
}

\begin{abstract}
The problem focus of this research is to improve students reading comprehension by using Know-Want-Learned (KWL), to make the students comprehend the text, And how the students make their own conclusion about the text. The object of this research was the eighth grade students of SMP Negeri 14 Palu that were divided into two group that was controlled group and experimental group. The aim was to know their improvement after the treatment of KnowWant-Learned (KWL) technique. This research was quantitative research, and the procedure of collected the data were observation, interview, Pre test, treatment, and Post Test. The data analysis used statistical analysis that was descriptive analysis. Statistical analysis is used to test the hypothesis. And the formula used to test the hypothesis was t-test with the level of significance 0,05 . The result showed that the application of Know-Want-Learned (KWL) strategy was successful in improving students' reading comprehension. It can be proven with the result of test of significance (t-test) was 0,2496. It means the result of t-test is more than level of significance $(0,05)$. Based on the conclusion above, suggested to the teacher especially English teacher is to use Know-Want-Learned (KWL) strategy or find out the other method to make the students interest to the material.
\end{abstract}

Keywords: Effectiveness, Reading, Comprehension, K-W-L Strategy. 


\section{Background}

English as a foreign language in Indonesia, it is make the Indonesian people and also the students founds difficulties in learning English, there are some factor why Indonesian students are difficult to learn English, such as: mother tongue, language system, and environment. That is why the Indonesian students felt difficult in English learning.

There are four English skills in English, they are: listening, speaking, reading, and writing. Listening competence is universally 'larger' than speaking competence. Speaking and listening skills are closely intertwined. The interaction between these two models of performance is applied especially to conversation, the most popular discourse category in the profession. Reading is also one of the most important skills in learning a language besides listening, speaking, and writing it is certainly not easy to present the English reading to Indonesian students whose language system different. ${ }^{1}$

Reading is very important for students in learning English. Because it is the main part of English learning that the student should mastered. By reading, the student could spell the word and

Most of students in Indonesia are difficult in English spelling, it is because of their ability in reading are still low, in other side, Indonesian students are also difficult to understand the meaning of the text that they have read. So that, they can read the text without understanding the meaning of the text.

Reading comprehension is really needed for Indonesian students to understand the meaning of the text, include English text. By improving their reading comprehension skill, it will help students to understand the meaning of the text, and they could analyzed the explicit and implicit meaning.

\footnotetext{
${ }^{1}$ Kustaryo, Sukirah. (1998) reading technique for college students. DEPDIKBUD.
}

The aim of teaching reading is to improving the student's ability in reading, so that they can read the text effectively and efficiently.

The problem face by the eighth grade students of SMP N 14 Palu is Most of the students in the class are passive and they are felt bored in the classroom during the learning process, especially in learning reading comprehension. The researcher taught that the students are getting boring because of the teaching strategy. The writer think that the teacher should find and apply the suitable strategy in learning process so that the teacher could improve the student's achievement in reading comprehension. According to the researcher, by using KWL (Know-Want-Learn) strategy the students could comprehend the text and the learning process will run well.

\section{Literature review}

Reading is a process of making meaning from written text. It needs the harmony of a lot of related sources of information. ${ }^{2}$ Reading is the process of creating meaning that involves: The readers' existing knowledge; The text information; and The reading context. ${ }^{3}$

Reading is an interactive process between readers and texts that result in reading fluency. Readers interact with texts as they try to extract meaning and there are different types of knowledge: linguistic or systematic knowledge (bottom up processing) and schematic knowledge (top-down processing). The main goal of reading is to gain the correct message from a text that a writer intended for the reader to receive. ${ }^{4}$

\footnotetext{
${ }^{2}$ Anderson, A. C. A schema-theoretic view of basic processes in reading.

${ }^{3}$ Wixson, K., Peters, C., Weber, E., Roeber, I. (1987). New direction in statewide reading assessment.The Reading Teacher,40(8), 749-755.

${ }^{4}$ Pourhosein Gilakjani, A., \&Ahmadi, S. M. (2011). The Relationship between L2 Reading Comprehension and Schema Theory: A Matter of Text Familiarity. International Journal of Information and
} 
Reading is one of the most Effective ways of foreign language learning. Reading simply is the interpretation of a written message. Reading as what the readers does to get the meaning he needs from contextual resource. In other word, reading is an activity of the readers to look for the new information from the written text.

The ability of reading is an interactive process between the readers and writers by text. Reading is the skill that should be mastered in learning English as foreign language. Kinds of text books and materials are written in English. It needs comprehension in reading the text to get better catching the idea and information. ${ }^{5}$ Reading Is the process to determine what the reader's brain, emotions and beliefs bring to the reading. It means that reading is the reader's way in interpreting the printed word. ${ }^{6}$ Reading is making sense of printed words.

Reading with comprehension means understanding what has been read. Comprehension involves understanding the vocabulary seeing the relationship among words and concepts, organizing idea, recognizing authors' purpose, making judgment and evaluating. ${ }^{7}$ Word is an important factor in determining the degree of comprehension. $^{8}$ Reading is a process of making sense of written idea through

Education Technology, I(2), 142-149.

http://dx.doi.org/10.77. V1.24

${ }^{5}$ NizaSyafeny, teaching reading comprehensionby using directed activities related to text (DRTA) for the students.,(LubukAlung, Jurnal Kata).,2017.

${ }^{6}$ Weaver, C. (2009). Reading Process Brief

Edition of Reading Process and Practice. (L Luedeke, Ed.). Ohio: Winthro Publisher, Inc.

${ }^{7}$ Nurdin, N. (2009). Segregasi Dalam Pengajaran Dan Penguasaan Bahasa. MUSAWA, 1(1), 23-41.

${ }^{8}$ Erika Sinambela, SondangManik,

RotuaElfridaPangaribuan. Improving Students' Reading

Comprehension Achievement by Using KWL

Sstrategy.(Medan, Sciedu Press). July 23, 2015. meaningful interpretation interaction with language. 9

From the statement above, we could conclude that reading comprehension is comprehend or understanding the text which has been read. It also as can be an activity of the readers to understand the information that is given on the text. To understand the text, it is very important to master many vocabularies.

Know-Want-Learned (KWL) is an instructional scheme that develops active reading expository text by activating learners' active knowledge. ${ }^{10}$ It is provided a structure for recalling what learners know about the topic. Noting what they want to know, and finally listing what has been learned and yet to be learned. Learners begin by brainstorming everything they know about the topic. The relevant information is recorded in the $K$ column of Know-Want-Learned (KWL) scheme. Learners then generate a list of questions about what they want to know about the topic. These questions are listed in the $\mathrm{W}$ column. During or after reading, learners answer these questions. What they have learned will $\mathrm{b}$ recorded in the $\mathrm{L}$ column.

Know-Want-Learned (KWL) Instructional Scheme

\begin{tabular}{|l|l|l|}
\hline \multicolumn{1}{|c|}{$\begin{array}{c}\mathbf{K} \\
\text { (what I know) }\end{array}$} & $\begin{array}{l}\text { W } \\
\text { (what I want to } \\
\text { learn) }\end{array}$ & \multicolumn{1}{c|}{$\begin{array}{c}\text { L } \\
\text { (what I learned) }\end{array}$} \\
\hline $\begin{array}{l}\text { Students list } \\
\text { everything they } \\
\text { think they know } \\
\text { about the topic } \\
\text { of study. }\end{array}$ & $\begin{array}{l}\text { Students tell } \\
\text { what they want } \\
\text { to know about } \\
\text { the topic. }\end{array}$ & $\begin{array}{l}\text { After the students } \\
\text { have finished } \\
\text { reading the topic, } \\
\text { they list what they } \\
\text { have learned. They } \\
\text { can also check the W } \\
\text { column to see which } \\
\text { questions were } \\
\text { answered and which } \\
\text { were left } \\
\text { unanswered. }\end{array}$ \\
& & \multicolumn{2}{|l}{} \\
& &
\end{tabular}

${ }^{9}$ Heilman, W. Athur.et.al.Principles and Practice of Teaching Reading. $5^{\text {th }}$. Ed. Bell \& Howell Company.

${ }^{10} \mathrm{Ibid}$, p. 570 


\section{Methodology}

The method design in this research was quasi-experiment. Quasi-experiment is a treatment or stimulus which administered by only one of two groups whose member that randomly assigned - are considered the gold standard in assessing causal hypotheses.

The design is as follow:

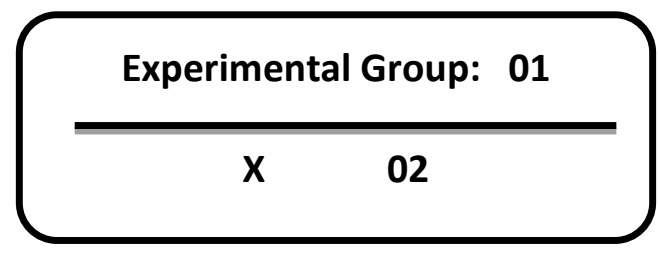

Where: (Sugiono, 2014)

$01=$ pre-test for experimental group

$02=$ post-test for experimental group

$03=$ pre-test for control group

$04=$ post-test for control group

$\mathrm{X}=$ treatment

The location of the research was at SMP Negeri 14 Palu, JL. Letjend Suprapto, Kec. Palu Timur, Palu city. The sample of this research are Hassanudin class as experimental group, and Panjaitan Class as Controlled group.

The technique of collecting data in this research was test. Which aim to improve the students understanding in reading the narrative text. The researcher was conducted the test through pre-test and post-test. The researcher asked the student to read the narrative text based on Know-Want-Learned (KWL) procedure.

\section{Result and Discussion}

In the observation it was found several factors that made the students were low in reading skill, there are:

a. Situation of the class

The situation of the class was not good, it was because of another activities in the outside were crowded, because of the activity of constructing a new building next to front of the class disturb the concentration of the students, then the students could not received lessons as well.

b. Student's basic in reading skill

One of the main problems faced by the students was their own basic in reading skill. It was found that when the researcher examined their reading skill, most of the students were difficult to pronounced the words correctly, and even more understood the meaning of a sentence. It made the students were lacks in reading comprehension.

Based on the findings in the observation, it was concluded that students were still low in reading skill even more in reading comprehension.

The result of the research was founded such as: the mean score of controlled group in pre test was $(66,6)$ and the standard deviation was $(10,1127)$, and the mean score of post test of controlled group was $(68,6)$ and the standard deviation was $(11,1365)$. The mean score of experimental group in Pre Test was (67) and the standard deviation was $(8,8819)$, and the mean score of experimental group in Post Test was $(84,4)$ and the standard deviation was $(5,5216)$. While the result of test of significance was $(0,2496)$.

\section{Conclusion and suggestions}

Based on the result of the research in chapter III, it concluded that the application of Know-Want-Learned (KWL) strategy can improve students' reading comprehension of the eight grade students of SMP Negeri 14 Palu. It was proven by the result of the test of significance was 0,2496 . It was more than the standard of significance 0,05 . It means, the hypothesis Ha was accepted, and HO was rejected. In other words, Know-WantLearned (KWL) strategy was effective in improving reading comprehension of the eight grade students of SMP Negeri 14 Palu.

There are several suggestions from the researcher to head master of SMP Negeri 
14 Palu, teachers, and students of SMP Negeri 14 Palu, and the other researcher are:

1. For the principal of SMP Negeri 14 Palu, it is useful to make an instructional concept in English subject especially in teaching reading by using Know Want Learned (KWL) strategy. And it can be applied in SMP Negeri 14 Palu, especially in English subject.

2. For the English teacher, it is useful to apply Know-Want-Learned (KWL) strategy as one of the alternative way in teaching reading to make a variation in teaching reading so that the students do not get bored in learning English especially in reading.

3. For the students, it is hoped that students improve their interest and their thinking to the material by using the concepts of Know-Want-Learned (KWL) strategy.

4. And the last for the other researcher, it is very useful as the information in conducting in depth research which is related to this research and it can be the one of the references of the research related to the Know-Want-Learned (KWL) strategy.

\section{References}

Agustin,Lesvetic. (2015). Improving

Students Reading Comprehension By

Using KWL Strategy At the

Eleventh Grade of MA Muhamdiyah 1

Ponorogo In the Academic

Year of 2013/2014. Universitas

Muhamadiyah Ponorogo.

Alderson, J.C. (2000). Assessing Reading.Cambridge: Cambridge University.

Anderson, R. C., \& Pearson, P. D. (1984).A schema-theoretic view of basic processes in reading.In P. D. Pearson, R.Barr, M. L. Kamil, \& P. Mosenthal (Eds.), Hand book of reading research (pp. 255-292). New York.
Arikunto, S. (2012) Dasar-Dasar Evaluasi Pendidikan Edisi 2. Jakarta: Bumi Aksara.

D, M, Ogle. (1986). K-W-L:A teaching Models That Develops Active Reading of Expository Text, Reading Teacher. New York: The Guilford, p.565-566.

Cadlin, N. Christopher \& Hall, R David.(2002). Teaching and Researching Reading. White plain: Pearson Education.

C, Ros and S, Vaughn. (2002) Strategies For Teaching Students With Learning and Behaviour Problems. USA: Rinehart and Winston, inc, p.179

David, C. (1979). Learning Strategies Resource Guide, Florida: Region XIV Comprehension Center, pp 11-14.

Dechant, V Emerald. (1982). Improving the teaching reading of reading third edition. Englewood Cliffss, New Jersey, Prentice-Hall Inc.

Erika Sinambela, SondangManik, RotuaElfridaPangaribuan. Improving Students' Reading

Comprehension Achievement by Using KWL Strategy.(Medan, Sciedu Press). July 23, 2015.

Gay, LR, 2006. Educational Research Competencies for Analysis and Applications. Second Edition. Florida International University. Ohio, Bell and Howel company.

HamdiahArief. 2017. The Effectiveness Of Talking Stick Method In Teaching Vocabulary At The Second Grade Of MtsMadaniPaopao.

Makassar: Hasanudin Islamic University.

Heilman, W. Athur.et.al.Principles and Practice of Teaching Reading. $5^{\text {th }}$. Ed. Bell \& Howell Company.

Hedge, T. (2003). Teaching and learning in the language classroom. UK:OUP

Kintsch, W. (1998).Comprehension: a paradigm for cognition. Cambridge, UK: Cambridge University Press. 
Kintsch, W. (1992).A cognitive architecture for comprehension. In H. L. Pick, P. van den Broek\& D. C. Knill (Eds.), Cognition: Conceptual and Methodological Issues, (pp. 143-163). Washington, DC: American Psychological Association.

Klingner. (2007). Teaching reading comprehension to students with learning difficulties. New York: The Guilford Press.

Kustaryo, Sukirah. (1998). Reading Techniques for College Students. DEPDIKBUD.

Lexico. (2019). British and world English. Oxford university

McKenna, M. C. \& Robinson, R. D. (1990). Content Literacy: a definition and implications. Journal of raeding, 34, 184-186.

Mohammad Hussein Hamdan. (2014). KWLPlus Effectiveness On Improving Reading Comprehension Of the Tenth Graders Of Jordanian Male Students. Theory And Practice In Language Studies 4 (11).

Nikmaturrahmah MS.A script: the implementation of $K-W-L$ strategy in teaching reading at the second gradeof MTs $N$ Tanggamus. language and arts education department, Lampung: University of Lampung, 2016.

NizaSyafeny, teaching reading comprehensionby using directed activities related to text (DRTA) for the students.,(LubukAlung, Jurnal Kata).,2017.

Nunan, David. 1998. Language Teaching Methodology: a Textbook for Teacher. London: Prentice Hall.
Nurdin, N. (2009). Segregasi Dalam Pengajaran Dan Penguasaan Bahasa. MUSAWA, 1(1), 23-41.

SalmiZakiYanti (cited Oakhil, op.cit.p.12). $a$ script: Improving Students' Achievement in Reading Comprehension by Using $K-W-L$ (Know-Want- Learned)Strategy in SMP Muhamadiyah 2 Medan in The Academic Year of 2016-1017. Department of English Education, Medan: State Islamic University of North Sumatera Medan, 2017.

Syafrini, Rezeki, HSB. 2017. Improving the Student's Achievements In Reading Narrative Text by Using know-WantLearned (KWL) Strategy At Grade Eight, MTs $N$ 3Medan Academic Year of 2017/2018. Medan: State Islamic University of North Sumatera.

PourhoseinGilakjani, A., \&Ahmadi, S. M. (2011). The Relationship between

L2 Reading Comprehension and Schema Theory: A Matter of Text Familiarity. International Journal of Information and Education Technology, I(2), 142-149. V1.24

Weaver, C. (2009). Reading Process Brief Edition of Reading Process and Practice.(L Luedeke, Ed.). Ohio: Winthro.

Willis, J. (2008). Teaching the brain to read strategies for improving fluency, vocabulary and comprehension. Alexandria: ASCD.

Wixson, K., Peters, C., Weber, E., Roeber, I. (1987). New direction in statewide reading assessment.The Reading Teacher,40(8), 749-755. 